\title{
Analysis of Zakat Core Principle Application in Lembaga Amil Zakat XYZ
}

\author{
Eka Ifa Apriliana, Dodik Siswantoro*
}

\author{
Faculty of Economics and Business, Universitas Indonesia, Depok, Indonesia \\ *Corresponding author. Email: dodik.siswantoro@ui.ac.id
}

\begin{abstract}
This study analyzes the application of Zakat Core Principles (ZCP) in zakat management in Lembaga Amil Zakat (LAZ) XYZ to determine its level of compliance with ZCP. Elaborating the compliance of zakat management in LAZ $\mathrm{XYZ}$ with ZCP serves as guidelines for LAZ XYZ to improve its effectiveness in zakat management. Results of the study in LAZ XYZ show that most zakat management rules of LAZ XYZ have been compliant with ZCP.
\end{abstract}

Keywords: Zakat, Zakat Core Principles, Amil Zakat Institution

\section{INTRODUCTION}

Zakat is the third pillar of Islam that refers to a particular portion of wealth deduction that is determined by Allah and has to be distributed to beneficiaries (Beik et al, 2016). It is one of the religious services that has a significant social dimension that aims to improve human welfare, that is, to alleviate poverty. During the administration of Khalifah Umar Bin Abdul Aziz, zakat had been proven to aid the welfare of the people considering that the level of "mustahiq" (beneficiaries) had risen to "muzakki" (benefactor). Presently, zakat funds have been distributed to people in other countries (Lapopo, 2012).

According to Prof. Dr. Magda Ismail in the International Conference on Inclusive Islamic Financial Sector (2014), zakat management is a problem in some Muslim countries. Furthermore, in his study, Beik (2015) suggested that zakat management has numerous global issues, such as regulatory framework, institutional capacity and performance including availability of qualified human resources, different interpretation of fiqh of zakat, and global zakat cooperation among Muslim countries to increase the quality of zakat management systematically so that potential of zakat in each country can be optimized. To overcome these global issues, an international body that manages zakat and alms, namely, the International Working Group Zakat and Shodaqoh, needs to be established.
In his study, Sasongko (2018) referred to Law No. 23/2011 on zakat management. He suggested that zakat aims to improve the effectiveness and efficiency of zakat management services and realize the people's welfare by alleviating poverty. To measure the effectiveness of zakat management services, we employ the allocation-to-collection ratio (ACR) method. ACR compares the zakat distributed with the zakat collected as an indicator of a zakat agency's zakat distribution.

Zakat Core Principles (ZCP) was initiated by Bank Indonesia (BI), Badan Amil Zakat Nasional (BAZNAS), Islamic Research and Training Institute (IRTI), and Islamic Development Bank (IDB). ZCP was realized in the initial meeting of the International Working Group on Zakat Core Principles (IWGZCP) in August 2014 in Jakarta. The discussion of ZCP was held in Indonesia from 2014 to 2015, in which several countries such as Pakistan, Malaysia, Saudi Arabia, Turkey, Bosnia, South Africa, Sudan, Singapore, and India were actively involved. The document of ZCP was legalized in the World Humanitarian Summit in Istanbul, Turkey from May 23 to 24, 2016.

The document of ZCP states its main objectives as the following: to improve the quality of zakat governance and optimize the potential of zakat. The document of ZCP is divided into six main dimensions, which are further subdivided into 18 principles. The six main dimensions are legal foundation, zakat supervision, zakat governance, intermediary function, risk management, and sharia's function. 
In their study, Rusydiana and Firmansyah (2017) prioritized the main principles in the five main dimensions of ZCP using the analytic hierarchy process. Regulation (34\%) ranks first, followed by audit and transparency (29\%), collection and distribution management $(22 \%)$, zakat supervision $(9 \%)$, and risk management $(6 \%)$.

Indonesia has zakat agencies that manage zakat funds at the national and district level, namely, BAZNAS and Lembaga Amil Zakat (LAZ), respectively. LAZ XYZ is one of the zakat agencies at the district level.

This study aims to analyze the application of ZCP in LAZ XYZ by comparing zakat management with ZCP as it can be applied to measure optimal zakat management. According to Bahri (2016), numerous studies have shown that Indonesia's zakat management needs improvement in several aspects to comprehensively optimize its efficiency.

This study is expected to contribute to the development of accounting, particularly in the field of sharia accounting, by discussing ZCP established to deal with global issues on zakat management in Islamic states. It is expected that Islamic states can identify zakat potentials and problems to enable them to find the best solution for optimal zakat management.

\section{LITERATURE REVIEW}

\subsection{Zakat}

According to the sharia terminology, zakat refers to a determined portion of wealth that has to be paid and distributed to beneficiaries who meet the criteria and conditions (Hafidhuddin, 2002). Zakat is legally based on the Surat Keputusan Dewan Pertimbangan BAZNAS No. 001/DP-BAZNAS/XII/2010 and is stipulated in Al Qur'an such as Qur'an Chapter At-Taubah Article 60 and Qur'an Chapter At-Taubah Article 103. In principle, zakat clears up wealth by distributing it to eligible beneficiaries called the eight asnaf, namely, the poor, the needy, amil zakat, jihad fi sabilillah (fighters in Allah's principles), gharimun (debtors), ibnus sabil (musafir), riqab (slaves), and mu'allaf.

Zakat is also stipulated in hadiths told by Bukhari, Abu Daud and Turmizi, the Five Narrators, Islam, Turmizi, and Thabrani. Based on the number of hadiths that regulate zakat, it can be concluded that zakat is distributed to the asnaf including persons who are studying the science of knowledge. Begging is prohibited, except for those who face severe burden, for example, from a disaster. Moreover, distributing zakat to the wealthy and healthy people is prohibited.

Stakeholders of zakat include the muzakki, mustahiq, and amil zakat. In his study, Nadhari (2013) revealed the mandatory conditions of zakat. According to Al-Zuhayly (1997), the conditions include independence, Islam, adulthood and mindfulness, wealth meeting the criteria for zakat deduction, wealth meeting the deducted ratio, deducted wealth fully owned, and wealth adequate to meet daily needs. According to Fakhruddin (2008), the legitimate condition of zakat is the intention of the muzakki and transfer of ownership from muzakki to mustahiq.

SK No. 001/DP-BAZNAS/XII/2010 Chapter 9 stipulates that the mustahiq's criteria include their inability to meet their al-hajjah al-asliyyah (basic needs). That is, their income should be equal to $\mathrm{Rp}$ 20.000 per day per capita or below the nominal income (Beik and Ayuniyyah, 2015). Chapter At-Taubah Article 60 of the Al Qur'an explains that zakat is exclusively reserved for the eight groups of asnaf. Islamic scholars have agreed that zakat is strongly prohibited from being distributed among anyone other than this group (Sharia Economics and Business Center - Faculty of Economics Universitas Indonesia 2011).

According to Law No. 23/2011, the organizations that manage zakat in Indonesia consist of BAZNAS Unit Pengumpul Zakat (the government) and LAZ (nongovernment organization of Islamic civil organizations) that are supported by local networks. According to Indonesian Ulema Council Fatwa No. 8 (2011), amil zakat is defined as a person or group of persons who are assigned by the government or society to manage zakat legally. To become an amil zakat, a person has to be Muslim, mukallaf (mindful and adult), trustworthy, and knowledgeable about the laws of zakat and matters related to the duties of amil zakat.

\subsection{Lembaga Amil Zakat}

LAZ is an institute established by the society to help the collection, distribution, and utilization of zakat. Law No. 23/2011 Article 17 stipulates that the society can establish LAZ to assist BAZNAS in the collection, distribution, and utilization of zakat. Moreover, Article 18 of Law No. 23/2011 regulates the establishment of LAZ, which has to be formally approved by religious minister. In addition, Law No. 23/2011 Article 19 stipulates that LAZ must report the periodical audit of collection, distribution, and utilization of zakat to BAZNAS. LAZ applicants need to mention the reasons accordingly.

\subsection{Zakat Core Principles}

ZCP was introduced as a follow-up to the IDB Expert Group Meeting in December 2012 in Jeddah. The meeting has resulted in an idea of developing an Islamic social finance that includes zakat, waqf, and Islamic microfinance. Subsequently, the Workshop on Islamic Social Finance was arranged in February 2013 
in Institut Pertanian Bogor. The workshop was attended by representatives from 13 countries. Later, IRTI and IDB published the Islamic Social Finance Report from 2014 to 2015.

BI, BAZNAS, IRTI, and IDB initiated the document of ZCP. The initiative was realized in the first meeting of the IWGZCP in August 2014 in Jakarta. The document of ZCP was officially introduced during the UN's World Humanitarian Summit in Istanbul, Turkey, from May 23 to 24, 2016.

$\mathrm{ZCP}$ is a starting point for the framework and practical standard of zakat-based management. It intends to improve the quality of the zakat management system by identifying the weaknesses of supervision and regulation among others (Rusydiana and Firmansyah, 2017). Zakat agencies have to be professional, transparent, and accountable in managing zakat. ZCP is currently known as the measure of zakat fund management (Rusydiana, Maliha and Al-Parisi, 2016). Digital transformation and technological development, such as crowdfunding platforms and mobile applications particularly in the banking system, have supported the collection of zakat funds. Similarly, zakat agencies need to adapt and develop digital zakat systems compliant with ZCP and the feasibility test of sharia finance institute (output of the 2nd International Conference Of Zakat 2018).

Poor zakat management is one of the causes of the large disparity between potential zakat collections and actual zakat collections. Therefore, the document of $\mathrm{ZCP}$ is introduced to overcome the various weaknesses in the existing zakat system. Table I describes the six core dimensions of ZCP in 18 principles.

Table I. Six Core Dimensions of Zakat Core Principles Elaborated in 18 Principles

\begin{tabular}{|c|c|c|c|}
\hline No & Core & \multicolumn{2}{|c|}{ ZCP } \\
\hline 1. & $\begin{array}{l}\text { Legal } \\
\text { foundation }\end{array}$ & & $\begin{array}{l}\text { Objective, independence, and power } \\
\text { Permissible activities } \\
\text { Licensing criteria }\end{array}$ \\
\hline 2. & $\begin{array}{l}\text { Zakat } \\
\text { supervision }\end{array}$ & & $\begin{array}{l}\text { Supervisory approach } \\
\text { Supervisory techniques and tools } \\
\text { Supervisory reporting }\end{array}$ \\
\hline 3. & $\begin{array}{l}\text { Zakat } \\
\text { governance }\end{array}$ & & $\begin{array}{l}\text { Corrective and sanctioning power of } \\
\text { zakat supervisor } \\
\text { Good amil governance }\end{array}$ \\
\hline 4 & $\begin{array}{l}\text { Intermediary } \\
\text { function }\end{array}$ & $\begin{array}{l}9 . \\
10 .\end{array}$ & $\begin{array}{l}\text { Collection management } \\
\text { Disbursement management }\end{array}$ \\
\hline 5. & $\begin{array}{l}\text { Risk } \\
\text { management }\end{array}$ & $\begin{array}{l}11 . \\
12 . \\
13 . \\
14 .\end{array}$ & $\begin{array}{l}\text { Country and transfer risk } \\
\text { Reputation and muzakki loss risk } \\
\text { Disbursement risk } \\
\text { Operational risk }\end{array}$ \\
\hline 6. & $\begin{array}{l}\text { Sharia's } \\
\text { function }\end{array}$ & $\begin{array}{l}15 . \\
16 . \\
17 . \\
18 .\end{array}$ & $\begin{array}{l}\text { Sharia's control and internal audit } \\
\text { Financial reporting and external audit } \\
\text { Disclosure and transparency } \\
\text { Abuse of zakat services }\end{array}$ \\
\hline
\end{tabular}

\section{RESEARCH METHOD}

This study employed a descriptive analysis method to identify the effect of the application of ZCP on the realization of good corporate governance by LAZ XYZ. The study was conducted in LAZ XYZ, one of the zakat management agencies located in the Central Jakarta. It has branch offices in various regions in Indonesia. Moreover, LAZ XYZ was chosen for this study because the Mosque Welfare Board or Dewan Kemakmuran Masjid (DKM) and other enterprises have made it the benchmark.

In-depth interviews were carried out to collect comprehensive and authentic information from the subjects (Marvasti, 2004). Data collected from the interviews mainly consisted of recorded audios and their transcripts and notes made by the interviewer. The notes may contain the content of the interview, participants' information, and context of the interview. The chief finance officer of LAZ XYZ was also interviewed.

This study used two types of data: primary and secondary. Primary data include results from oral and written interviews with the participants. Secondary data include the profile and internal regulation processes of LAZ XYZ such as the standard operating procedure (SOP), organizational mechanism (TKO), statutes (AD), and rules of association (ART).

The researcher qualitatively and descriptively analyzed the data. The collected data were processed and interpreted to comprehensively explain the existing issues. Data analysis was conducted by comparing the results of the literature review with those of the interviews regarding the application of ZCP in LAZ $X Y Z$. By comparing the two types of data, the researcher analyzed the advantages and disadvantages of the application of ZCP to LAZ XYZ.

The questions were developed on the basis of the elaboration of the principles contained in the document of ZCP. During the interview with LAZ XYZ, the researchers also discussed each principle of the $\mathrm{ZCP}$ guidelines. The answers were coded by analyzing the zakat management in LAZ XYZ to determine if it has been compliant with the ZCP. If it was found to have been compliant, it was labeled "compliant" and "noncompliant" if otherwise. Compliance and noncompliance of zakat management in LAZ XYZ with the ZCP guidelines were elaborated.

\section{ANALYSIS}

Table II shows an analysis of the application of the 18 principles of ZCP in LAZ XYZ by focusing on the compliance and non-compliance of zakat management in LAZ XYZ with ZCP. 
Table II. Analysis of Zakat Core Principles

\begin{tabular}{|c|c|c|c|c|}
\hline $\mathrm{ZCP}$ & $\begin{array}{l}\mathrm{ZCP} \\
\text { Principles }\end{array}$ & ZCP Guidelines & Compliance & Application \\
\hline $\begin{array}{l}\mathrm{ZCP} \\
1\end{array}$ & $\begin{array}{l}\text { Objective, } \\
\text { independence, } \\
\text { and power }\end{array}$ & $\begin{array}{l}\text { The objective of supervising } \\
\text { zakat, the legal basis of zakat, } \\
\text { and the power of zakat } \\
\text { supervisors }\end{array}$ & Compliant & $\begin{array}{l}\text { LAZ XYZ objectively complies with the regulation of sharia, the } \\
\text { prevailing law of Al Qur'an and hadiths, Law No. 23/2011, and } \\
\text { Peraturan Pemerintah No. 14/2014. The job description of the } \\
\text { supervisory board is stipulated in AD of LAZ XYZ, which } \\
\text { includes supervising and providing advice to managers in } \\
\text { implementing the activities of BAZNAS. In case of a violation of } \\
\text { the regulation, the board of trustees may dismiss the member of } \\
\text { the Supervisory Board who committed the violation. }\end{array}$ \\
\hline \multirow[t]{2}{*}{$\begin{array}{l}\mathrm{ZCP} \\
2\end{array}$} & \multirow[t]{2}{*}{$\begin{array}{l}\text { Permissible } \\
\text { activities }\end{array}$} & $\begin{array}{l}\text { Source of zakat, general } \\
\text { criteria of zakat, payment } \\
\text { criteria of zakat, and } \\
\text { management of ZCP and } \\
\text { other religious funds }\end{array}$ & Compliant & $\begin{array}{l}\text { The sources of zakat are zakat mal such as gold and money as well } \\
\text { as zakat fitrah. The general criteria of zakat are compliant with } \\
\text { Article } 21-24 \text { of Law No. } 23 / 2011 \text {. The payment criteria are based } \\
\text { on the priority scale by considering an even distribution, justice, } \\
\text { and geographic condition. LAZ XYZ manages the waqf fund and } \\
\text { fidyah and kafarat during Ramadan. }\end{array}$ \\
\hline & & $\begin{array}{l}\text { List of licensed agencies } \\
\text { accessible to the public }\end{array}$ & $\begin{array}{l}\text { Non- } \\
\text { compliant }\end{array}$ & It has not opened access to the licensed agencies to the public. \\
\hline $\begin{array}{l}\mathrm{ZCP} \\
3\end{array}$ & $\begin{array}{l}\text { Licensing } \\
\text { criteria }\end{array}$ & $\begin{array}{l}\text { Licenses and permits } \\
\text { including licensed rights and } \\
\text { the authority in charge of the } \\
\text { issuance of a license }\end{array}$ & Compliant & $\begin{array}{l}\text { The licensed right of LAZ XYZ derives from the decree of the } \\
\text { religious minister, the deed of establishment of LAZ XYZ as one } \\
\text { of the conditions to obtain the license. The authorities in charge of } \\
\text { the issuance are BAZNAS and the Ministry of Religious Affairs. }\end{array}$ \\
\hline \multirow[t]{2}{*}{$\begin{array}{l}\mathrm{ZCP} \\
4\end{array}$} & \multirow[t]{2}{*}{$\begin{array}{l}\text { Supervisory } \\
\text { approach }\end{array}$} & $\begin{array}{l}\text { Structure of zakat } \\
\text { management }\end{array}$ & Compliant & LAZ XYZ's structure comprises SOP, TKO, AD, and ART. \\
\hline & & Risk assessment method & $\begin{array}{l}\text { Non- } \\
\text { compliant }\end{array}$ & Supervisors lack methods of determining and assessing risk. \\
\hline \multirow[t]{2}{*}{$\begin{array}{l}\mathrm{ZCP} \\
5\end{array}$} & \multirow[t]{2}{*}{$\begin{array}{l}\text { Supervisory } \\
\text { techniques } \\
\text { and tools }\end{array}$} & $\begin{array}{l}\text { Evaluation of performance } \\
\text { and monitoring }\end{array}$ & Compliant & $\begin{array}{l}\text { LAZ XYZ performs internal audit to evaluate the performance of } \\
\text { the internal auditor system (SPI) department. Supervisors monitor } \\
\text { the SPI through managers' reports. To follow-up, the supervisors } \\
\text { make recommendations to the board of trustees. }\end{array}$ \\
\hline & & $\begin{array}{l}\text { System and tools of } \\
\text { supervision and independent } \\
\text { third parties }\end{array}$ & $\begin{array}{l}\text { Non- } \\
\text { compliant }\end{array}$ & LAZ XYZ lacks a special supervision system for external audit. \\
\hline $\begin{array}{l}\mathrm{ZCP} \\
6\end{array}$ & $\begin{array}{l}\text { Supervisory } \\
\text { reporting }\end{array}$ & $\begin{array}{l}\text { Accurate and timely financial } \\
\text { reports, validity, and integrity }\end{array}$ & Compliant & $\begin{array}{l}\text { Financial reports are accurate and timely and are submitted not } \\
\text { later than the } 15 \text { th of the current year. Data from well-arranged } \\
\text { complete documents are valid, and supporting documents are } \\
\text { available. }\end{array}$ \\
\hline $\begin{array}{l}\text { ZCP } \\
7\end{array}$ & $\begin{array}{l}\text { Corrective and } \\
\text { sanctioning } \\
\text { power of zakat } \\
\text { supervisors }\end{array}$ & $\begin{array}{l}\text { Tools of supervision, quick } \\
\text { sanction, and sanction for the } \\
\text { board and individuals }\end{array}$ & Compliant & $\begin{array}{l}\text { Supervisors conduct surprise examinations of papers and } \\
\text { documents in the office. They reprimand and give warnings } \\
\text { directly. Sanctions are given to the board and individuals when } \\
\text { they commit mild or severe violence. }\end{array}$ \\
\hline $\begin{array}{l}\mathrm{ZCP} \\
8\end{array}$ & $\begin{array}{l}\text { Good amil } \\
\text { governance }\end{array}$ & $\begin{array}{l}\text { Share of amil, a guideline for } \\
\text { zakat governance, policy and } \\
\text { practice of governance, } \\
\text { conditions of potential } \\
\text { employees, Islamic values } \\
\text { and ethical code, and change } \\
\text { in the structure of the board } \\
\text { members }\end{array}$ & Compliant & $\begin{array}{l}\text { Share of amil is } 12.5 \% \text {. Zakat management in LAZ XYZ has } 12 \\
\text { procedural guidelines. The regulation is issued by the supervisor } \\
\text { and is acknowledged by the board of trustees. Terms and } \\
\text { conditions of employees' trusteeship and skills are declared. } \\
\text { Recruitment of managers involves the sharia board and is decided } \\
\text { in the joint meeting of LAZ XYZ. The structure of the board may } \\
\text { change in case the members fail to meet their obligation. }\end{array}$ \\
\hline $\begin{array}{l}\mathrm{ZCP} \\
9\end{array}$ & $\begin{array}{l}\text { Collection } \\
\text { management }\end{array}$ & $\begin{array}{l}\text { Deduction and collection of } \\
\text { zakat, setting up the nishab, } \\
\text { evaluation of the asset of } \\
\text { zakat, proactive collection, } \\
\text { prioritization of zakat fund, } \\
\text { prompt collection of zakat } \\
\text { fund }\end{array}$ & Compliant & $\begin{array}{l}\text { Fundraising in LAZ XYZ is determined directly. The supervisors } \\
\text { determine the nishab of income source and wealth accumulation. } \\
\text { The zakat agency mandates the determination of tariff if the } \\
\text { nishab is compliant and the income source has categorized the } \\
\text { zakat. LAZ XYZ collects zakat proactively, gives higher priority } \\
\text { to the zakat fund than other funds, and collects the zakat fund } \\
\text { promptly. }\end{array}$ \\
\hline $\begin{array}{l}\mathrm{ZCP} \\
10\end{array}$ & $\begin{array}{l}\text { Disbursement } \\
\text { management }\end{array}$ & Disbursement management & Compliant & $\begin{array}{l}\text { Identification of asnaf is based on the guidelines in LAZ XYZ. } \\
\text { The zakat fund is separated from the government's income. The } \\
\text { zakat criteria of beneficiaries are compliant with Qur'an Chapter } \\
\text { At-Taubah Article } 60 \text {. The proportion of consumption and } \\
\text { production are approximately } 90 \% \text { and } 10 \% \text {, respectively. The } \\
\text { remaining fund not distributed is limited to two months. The }\end{array}$ \\
\hline
\end{tabular}




\begin{tabular}{|c|c|c|c|c|}
\hline $\mathrm{ZCP}$ & $\begin{array}{l}\text { ZCP } \\
\text { Principles }\end{array}$ & ZCP Guidelines & Compliance & Application \\
\hline & & & & $\begin{array}{l}\text { priority scale of asnaf is approximately } 70 \% \text { for the needy. } \\
\text { Fairness, justice, and regional proximity are implemented in } \\
\text { Jabodetabek. LAZ XYZ employs verifiers. The distribution of } \\
\text { funds is limited to the partners maximally once a year. }\end{array}$ \\
\hline & & & $\begin{array}{l}\text { Non- } \\
\text { compliant }\end{array}$ & $\begin{array}{l}\text { The criteria of zakat beneficiaries are not disclosed to the public } \\
\text { and have not used ACR. }\end{array}$ \\
\hline $\begin{array}{l}\mathrm{ZCP} \\
11\end{array}$ & $\begin{array}{l}\text { Country and } \\
\text { transfer risk }\end{array}$ & State risk and transfer risk & Compliant & $\begin{array}{l}\text { Distribution of aid by LAZ XYZ is done through a state agency, } \\
\text { that is, the Ministry of Social Affairs of Indonesia. }\end{array}$ \\
\hline $\begin{array}{l}\mathrm{ZCP} \\
12\end{array}$ & $\begin{array}{l}\text { Reputation } \\
\text { and muzakki } \\
\text { loss risk }\end{array}$ & $\begin{array}{l}\text { Reputation risk, } \\
\text { strategy to minimize loss risk } \\
\text { of muzakki, and zakat } \\
\text { socialization }\end{array}$ & Compliant & $\begin{array}{l}\text { When the muzakki pay zakat via payroll, they get a monthly report } \\
\text { of the zakat payment on the } 5 \text { th of every month. The financial } \\
\text { report of LAZ XYZ also presents photos, and its socialization is } \\
\text { disclosed in the enterprise's website. }\end{array}$ \\
\hline \multirow[t]{2}{*}{$\begin{array}{l}\mathrm{ZCP} \\
13\end{array}$} & \multirow[t]{2}{*}{$\begin{array}{l}\text { Disbursement } \\
\text { risk }\end{array}$} & $\begin{array}{l}\text { Risk of payment, minimizing } \\
\text { mistakes in payment } \\
\text { allocation, and verification of } \\
\text { information about financial } \\
\text { risk }\end{array}$ & Compliant & $\begin{array}{l}\text { Annual Performance Plan and Budget, Zakat payments made by } \\
\text { individuals are checked and signed by the manager. Papers are } \\
\text { also verified to control payment risk. }\end{array}$ \\
\hline & & $\begin{array}{l}\text { Renewal of financial } \\
\text { administration }\end{array}$ & $\begin{array}{l}\text { Non- } \\
\text { compliant }\end{array}$ & LAZ XYZ lacks renewal of financial administration. \\
\hline \multirow[t]{2}{*}{$\begin{array}{l}\mathrm{ZCP} \\
14\end{array}$} & \multirow[t]{2}{*}{$\begin{array}{l}\text { Operational } \\
\text { risk }\end{array}$} & $\begin{array}{l}\text { Operational risk and sharia } \\
\text { risk }\end{array}$ & Compliant & $\begin{array}{l}\text { Internal audit and sharia control are conducted by the SPI and } \\
\text { board of sharia of the enterprise, respectively. }\end{array}$ \\
\hline & & $\begin{array}{l}\text { Special unit in charge of the } \\
\text { risks }\end{array}$ & $\begin{array}{l}\text { Non- } \\
\text { compliant }\end{array}$ & $\begin{array}{l}\text { LAZ XYZ lacks a special unit that deals with operational risk and } \\
\text { sharia risk. }\end{array}$ \\
\hline $\begin{array}{ll}\mathrm{ZCP} \\
15\end{array}$ & $\begin{array}{l}\text { Sharia's } \\
\text { control and } \\
\text { internal audit }\end{array}$ & $\begin{array}{l}\text { Internal audit and functions of } \\
\text { internal audit }\end{array}$ & Compliant & $\begin{array}{l}\text { Internal audit is stipulated in AD, ART, SOP, and TKO. In LAZ } \\
\mathrm{XYZ} \text {, internal audit is monitored by the SPI of the enterprise. }\end{array}$ \\
\hline $\begin{array}{l}\mathrm{ZCP} \\
16\end{array}$ & $\begin{array}{l}\text { Financial } \\
\text { reporting and } \\
\text { external audit }\end{array}$ & External audit & $\begin{array}{l}\text { Non- } \\
\text { compliant }\end{array}$ & LAZ XYZ lacks external audit. \\
\hline \multirow[t]{2}{*}{$\begin{array}{l}\mathrm{ZCP} \\
17\end{array}$} & \multirow{2}{*}{$\begin{array}{l}\text { Disclosure } \\
\text { and } \\
\text { transparency }\end{array}$} & Qualitative report & Compliant & $\begin{array}{l}\text { A qualitative report is provided in the form of notes to financial } \\
\text { statement and a program report. }\end{array}$ \\
\hline & & $\begin{array}{l}\text { Disclosure of consolidated } \\
\text { information }\end{array}$ & $\begin{array}{l}\text { Non- } \\
\text { compliant }\end{array}$ & LAZ XYZ does not provide financial reports to the public. \\
\hline \multirow[t]{2}{*}{$\begin{array}{l}\mathrm{ZCP} \\
18\end{array}$} & \multirow[t]{2}{*}{$\begin{array}{l}\text { Abuse of } \\
\text { zakat services }\end{array}$} & $\begin{array}{l}\text { Internal control of criminal } \\
\text { acts }\end{array}$ & Compliant & $\begin{array}{l}\text { Control is implemented in the form of verbal reprimand, written } \\
\text { sanction, and dishonored dismissal. }\end{array}$ \\
\hline & & $\begin{array}{l}\text { Policy of promoting Islamic } \\
\text { ethics }\end{array}$ & $\begin{array}{l}\text { Non- } \\
\text { compliant }\end{array}$ & $\begin{array}{l}\text { LAZ XYZ lacks policies that promote Islamic ethics and prevent } \\
\text { criminal acts such as tausiyah. }\end{array}$ \\
\hline
\end{tabular}

\section{CONCLUSION AND IMPLICATION}

Based on the aforementioned analysis and discussion, it can be concluded that the application of ZCP in LAZ XYZ emphasizes the importance of compliance to improve the effectiveness of zakat supervision. However, the numerous criteria that have been met do not necessarily indicate LAZ XYZ's level of compliance with ZCP. The compliance of the application of ZCP in LAZ XYZ is indicated by nine principles of ZCP, namely, ZCP 1 (objective, independence, and power), ZCP 3 (licensing criteria), ZCP 6 (supervisory reporting), ZCP 7 (corrective and sanctioning power of zakat supervisors), ZCP 8 (good amil governance), ZCP 9 (collection management), ZCP
11 (country and transfer risk), ZCP 12 (reputation and muzakki loss risk), and ZCP 15 (sharia's control and internal audit).

Non-compliance has to be observed and improved to reach full compliance with ZCP. Compliance with prevailing regulations and laws is observable. Zakat management in LAZ XYZ has not been ideal in the implementation of nine principles of ZCP, namely, ZCP 2 (permissible activities), ZCP 4 (supervisory approach), ZCP 5 (supervisory techniques and tools), ZCP 10 (disbursement management), ZCP 13 (disbursement risk), ZCP 14 (operational risk), ZCP 16 (financial reporting and external audit), ZCP 17 (disclosure and transparency), and ZCP 18 (abuse of zakat services). 
It is suggested that in the application of ZCP, LAZ $\mathrm{XYZ}$ employs external audit on its financial reports. It has to re-formulate its sanction policy for minor and major violence, though the financial report of the central office and unit offices of LAZ XYZ have been consolidated every month. However, it is recommended that LAZ XYZ implements the program collectively for an even distribution of the collected funds throughout Indonesia. LAZ XYZ should employ working age individuals to implement the program and financial reporting system. By doing this, it is expected that the consolidated data entry will have no obstacles.

\section{RESEARCH LIMITATIONS}

The limitation of the study is that not all countries and zakat agencies apply ZCP in zakat management. With regard to transparency, we found that LAZ XYZ and BAZNAS have no external audit. In addition, the financial report is not disclosed to the national public. Thus, additional informants and different methods of study are necessary for a more effective application of ZCP. Each point in ZCP has to be elaborated as indicators of evaluation.

\section{REFERENCES}

[1] Al-Zuhayly, W. (1997). Zakat study of various mazhab. Bandung: PT Remaja Rosdakarya , p98.

[2] Bahri, A. (2016). Zakat as an instrument of economic development for people's welfare. $\mathrm{Li}$ Falah Jurnal Studi Ekonomi dan Bisnis Islam, 1(2), p74-89.

[3] Beik, I. S. (2015). Towards International Standardization of Zakat System. In Fiqh Zakat International Conference, p3-17.

[4] Beik, I.S. and Ayuniyyah, Q. (2015) 'Fiqh of asnaf in the distribution of zakat: Case study of The National Board of Zakat Of Indonesia (BAZNAS)', Al-Infaq: Jurnal Ekonomi Islam, 6(2), p201-216.

[5] Beik, I.S., Hanum, H., Muljawan, D., Yumanita, D., Fiona, A. and Nazar, J.K. (2016) 'Consultative document, core principles for effective zakat supervision', BAZNAS and BI.
[6] Fakhruddin. (2008). Fiqh of zakat management in Indonesia. Malang: PT UIN Malang Press, p34.

[7] Hafidhuddin, D. (2002). Zakat in the modern economy. Jakarta: Gema Insani, p7.

[8] Indonesian Ulema Council. (2011). Indonesian Ulema Council Fatwa Number 8 of 2011 concerning Amil Zakat.

[9] Ismail, M. (2014). 'International conference on inclusive Islamic financial sector. The role of zakah and awqaf as financial safety net'. Bank Indonesia.

[10] Lapopo, J. (2012). Effects of ZIS (Zakat, Infaq, Sadaqah) and Zakat Fitrah on Poverty Reduction in Indonesia Period 1998-2010. Media Ekonomi, 20(1).

[11] Marvasti, A. (2004) Qualitative research in sociology. London: Sage Publications.

[12] Nadhari, A.K. (2013). Management of Zakat in the Muslim World. Economic: Jurnal Ekonomi dan Hukum Islam, 3(2), p54-72.

[13] Sharia Economics and Business Center - Faculty of Economics Universitas Indonesia. (2011). Indonesia Shari'ah Economic Outlook (ISEO) 2011. Jakarta: Lembaga Penerbit Fakultas Ekonomi Universitas Indonesia.

[14] Rusydiana, A.S. and Firmansyah, I. (2017) 'Prioritizing zakat core principles (ZCP) criteria', Esensi: Jurnal Bisnis dan Manajemen, 7(2), p277302.

[15] Rusydiana A.S., Maliha, H. and Al-Parisi, S (2016) 'Efficiency measurement of Zakat Institution Program: Case study dompet dhuafa Indonesia', International Jurnal of Islamic Business Ethics (IJIBE), 1(1), p28-43.

[16] Sasongko, F. (2018), Efficiency and Effectiveness Analysis of Performance Management of Zakat, Infaq, Sadaqah Funds (ZIS) (Study of 3 Zakat Management Organizations in East Java for 20142016), Fakultas Ekonomi UIN Maulana Malik Ibrahim,

Malang 